\title{
China's Slowdown: Is Currency Appreciation to Blame?
}

\author{
Paulina Restrepo-Echavarria, Economist
}

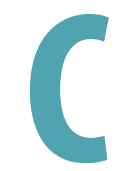

hina's economy is believed to be highly dependent on exports. If it is, then keeping the value of its currency low would be important for China's economic growth-cheaper exports are more attractive. This essay examines the relationship between China's economic slowdown and its currency appreciation.

After the Asian crisis in 1998-99, China fixed its currency to the U.S. dollar (USD). This remained the case until 2005, when China decided to gradually increase the value of the yuan (CNY). As a result of this policy, within three years the CNY revaluated around 17 percent against the USD. But then the U.S. subprime mortgage crisis led to a decline in world trade and exerted competitive pressure on Chinese exporters. Around August 2008, China reversed its policy and "re-pegged" its currency to the USD. In June 2010, China's central bank announced that it would return to a more flexible exchange rate. Since then, the CNY has appreciated around 10 percent against the USD (see Figure 1). ${ }^{1}$

\section{Evidence suggests that the exchange rate appreciation is not to blame for China's slowdown.}

Even though China argues that its currency has been pegged to a basket of currencies since 2010, in practice it is loosely pegged to the USD (Figure 1). Over the past two years (2013-15), the USD/CNY exchange rate has remained fairly constant. As a result, as the USD gained value against most currencies, so did the CNY. In trade-weighted terms, the CNY is at an all-time high (see the dashed line in Figure 1).

A highly appreciated CNY implies that Chinese exports have become more expensive, losing competitiveness in world markets. If this change in prices translates to a

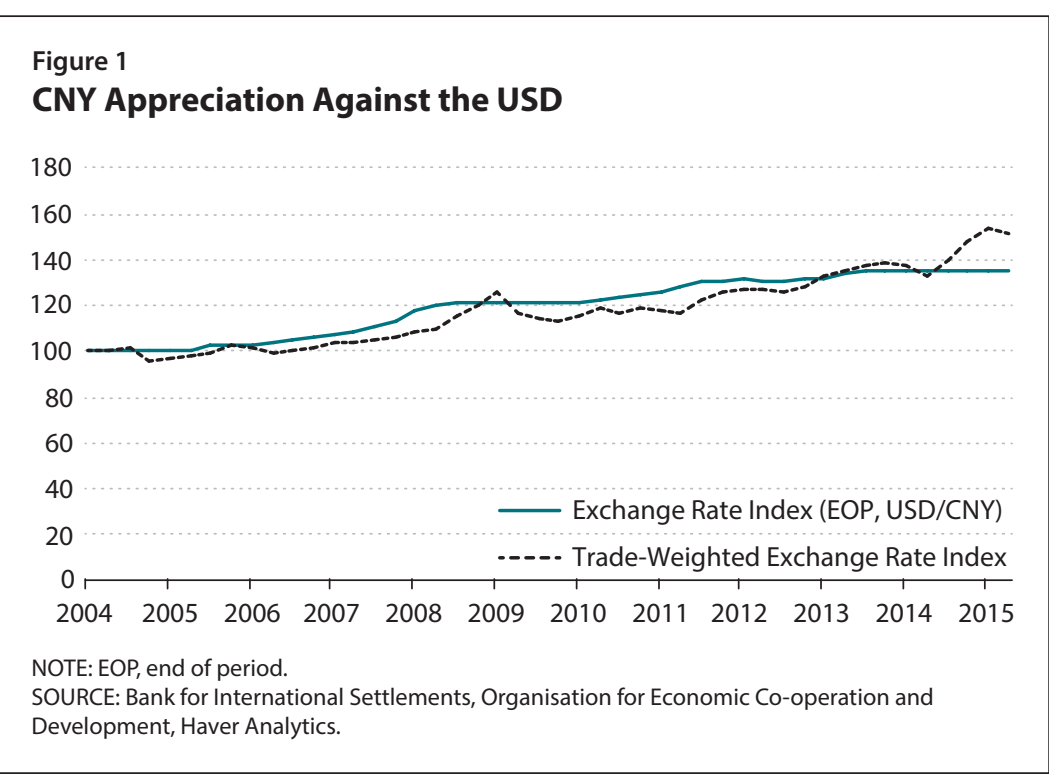

decrease in exports and a sufficiently high fraction of China's gross domestic product (GDP) growth depends on the growth of exports, then the currency appreciation can translate to an economic slowdown.

This hypothesis can be evaluated by looking at two decompositions: (i) that of China's GDP into all its main components and (ii) that of China's GDP growth rate into the growth rate of all its components. As Figure 2 shows, exports accounted for at most 35 percent of China's GDP (in 2006) and their importance has decreased over the years, especially compared with investment and private consumption.

In addition, as shown in Figure 3, the contribution of net exports to GDP growth has moved both up and down during China's slowdown, which started in 2010. The contribution of net exports to GDP growth has been changing over the years and does not seem to show any systematic behavior. Overall, two facts suggest that the exchange rate appreciation is not to blame for China's slowdown. First, investment and consumption seem to be much larger 
drivers of China's GDP growth (see Figure 3). And second, the contribution of the growth rate of net exports has not shown a systematic decline since the start of the slowdown. At least this is the case when one thinks about the simplest direct channel through which a currency exchange rate can affect growth: A currency appreciation makes exports more expensive, exports shrink by a large amount; and if they constitute a large share of GDP, then GDP growth will suffer.

Finally, it is also important to note that China has been running a current account surplus. The current account is defined as net exports minus income from abroad and current transfers, which is also equal to savings minus investment. If savings are higher than investment, then there is a current account surplus. This has been the case in China, a country known for high savings. This means that the current account surplus-and, hence, the positive net exports-can be due to the high levels of savings, making the exchange rate channel mentioned above weaker and less relevant for economic growth.

\section{Note}

1 See ECR Research. "China's Exchange Rate Policy"; http://www.ecrresearch.com/chinas-exchange-rate-policy. Accessed October 16, 2015.
Figure 2

\section{Decreasing Importance of Chinese Exports Over Time}

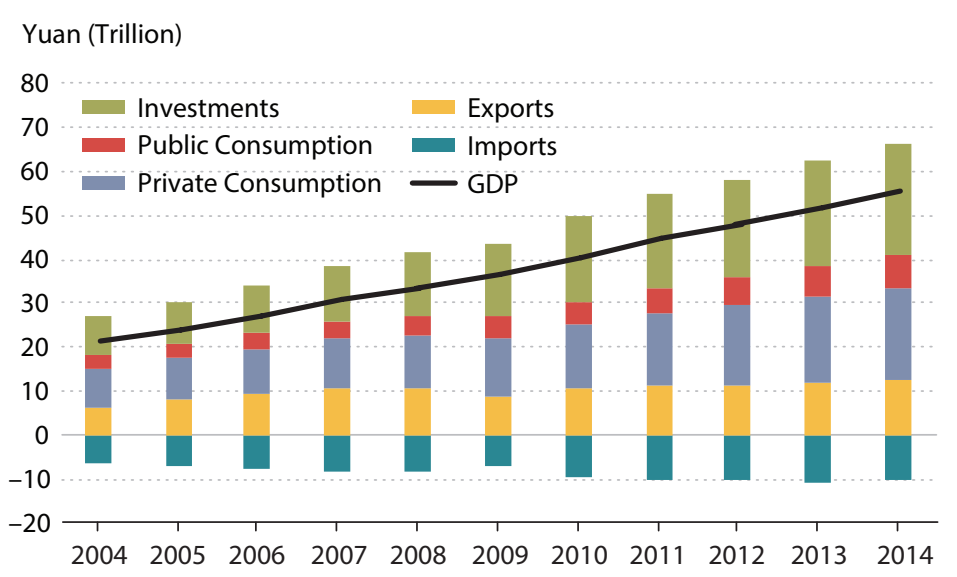

SOURCE: China National Bureau of Statistics, Organisation for Economic Co-operation and Development, Haver Analytics.

Figure 3

\section{Contribution of Net Exports to China's GDP Growth}

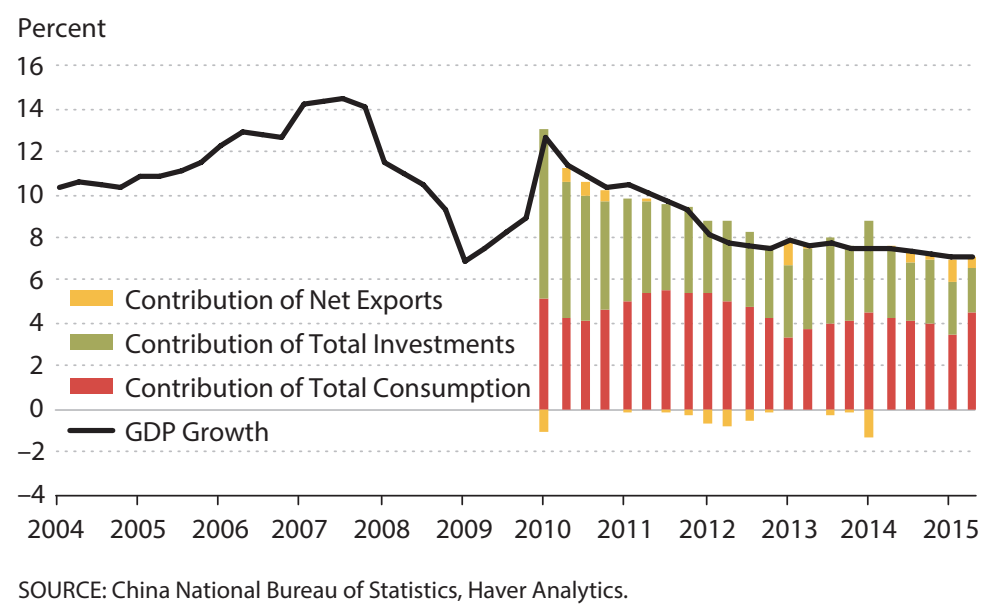

